\title{
Helicobacter pylori infection in HIV-positive patients with digestive complaints
}

\author{
Infecţia cu Helicobacter pylori la pacienţii seropozitivi HIV \\ cu acuze digestive
}

\author{
Nina-Ioana Şincu ${ }^{1 *}$, Lucia Carmen Chiriac ${ }^{1}$, Marta Andrea Fodor ${ }^{2}$, \\ Andrea Incze ${ }^{2}$, Simona Băţagă ${ }^{3}$ \\ University of Medicine and Pharmacy Tirgu-Mures \\ 1. Department of Infectious Diseases, 2. Department of Laboratory Medicine, 3. Department of \\ Internal Medicine I
}

\begin{abstract}
Background. Patients infected with human immunodeficiency virus (HIV), especially at advanced stages of HIV infection and low CD4+ T-lymphocytes levels, were reported to be less frequently co-infected with Helicobacter pylori than general population, according to literature data. Purpose: to study Helicobacter pylori infection in HIV-positive hosts with digestive complaints. Methods: retrospective, analytical, case-control study (November 2011 - December 2013), upon two groups of patients with gastro-intestinal symptoms tested for Helicobacter pylori stool antigen at the Infectious Diseases Laboratory, Clinical County Hospital Mureş. Group A included 44 HIV-positive patients, group B: 58 HIV-negative subjects. We first compared groups A and B regarding the frequency of Helicobacter pylori infection. Group A was afterwards divided into two sub-groups, according to the status of Helicobacter pylori infection: group A1: 5 Helicobacter pylori-positive subjects, group A2: 39 Helicobacter pylori-negative ones. We collected information regarding CD4+ T-lymphocytes level, HIV-RNA plasma viral load, previous antibiotic and antiretroviral therapy, co-morbidities, comparing A1 and A2 subgroups. Data were processed using GraphPad Prism 5 programme. Results. The frequency of Helicobacter pylori infection was 11.36\% among HIV-positive patients and $13.79 \%$ in HIV-negative ones, without statistically significant difference. We found no statistically significant differences between subgroups A1 and A2 regarding CD4+ T-lymphocytes level, HIV-RNA plasma viral load, antibiotic / antiretroviral therapy. Conclusions. Though Helicobacter pylori infection may represent one of the causes of gastro-intestinal symptoms in HIV-positive patients, its frequency did not differ to that registered in the general population, in our study.
\end{abstract}

Keywords: Helicobacter pylori; human immunodeficiency virus;stool antigen detection.

\section{Rezumat}

Introducere. Datele din literatura de specialitate raportează o frecvenţă mai scăzută a infecţiei cu Helicobacter pylori în rândul pacienţilor infectaţi cu virusul imunodeficienţei umane (HIV), în special la nivele scăzute ale

*Corresponding author: Nina-Ioana Şincu, University of Medicine and Pharmacy Tirgu-Mureș, Romania, e-mail: ninasincu@yahoo.com 
limfocitelor T CD4+ sau în stadii avansate ale infecţiei HIV. Scopul lucrării: studiul infecţiei cu Helicobacter pylori la pacienţii seropozitivi HIV cu acuze digestive. Material si metode: studiu retrospectiv, analitic, cazcontrol (noiembrie 2011 - decembrie 2013), pe două loturi de pacienţi cu simptome gastro-intestinale, la care s-a determinat coproantigenul Helicobacter pylori la Laboratorul Boli Infecţioase, Spitalul Clinic Judeţean Mureş. Grupul A includea 44 pacienţi HIV-pozitivi, grupul B 58 subiecţi HIV-negativi. După ce am comparat frecvenţa infecţiei cu Helicobacter pylori în grupurile A şi B, am împărţit grupul A în două subgrupuri: A1, alcătuit din 5 pacienţi Helicobacter pylori-pozitivi şi A2, format din 39 pacienţi Helicobacter pylori-negativi, pe care le-am comparat în privinţa nivelului limfocitelor T CD4+, încărcăturii virale plasmatice HIV-ARN, terapiei antibiotice I antiretrovirale. Analiza statistică a fost efectuată folosind programul GraphPad Prism 5. Rezultate: Frecvenţa infecţiei cu Helicobacter pylori a fost $11.36 \%$ la pacienţii HIV-pozitivi şi 13.79\% la subiecţii HIV-negativi, fără diferenţă semnificativă statistic. Nu am înregistrat diferenţe semnificative statistic intre subgrupurile A1 şi A2 privind nivelul limfocitelor T CD4+ ( $p=0.3258)$, incărcătura virală HIV-ARN plasmatică, terapia antibiotică sau antiretrovirală. Concluzii: Infecţia cu Helicobacter pylori poate reprezenta una dintre cauzele simptomatologiei gastro-intestinale la pacienţii seropozitivi HIV, însă frecvenţa sa nu diferă de cea înregistrată în populaţia generală in studiul nostru.

Cuvinte cheie: Helicobacter pylori; virusul imunodeficienţei umane; coproantigen Helicobacter pylori.

Received: $1^{\text {st }}$ February 2014; Accepted: $1^{\text {st }}$ June 2014; Published: $7^{\text {th }}$ June 2014.

\section{Introduction}

Among various co-infections incriminated in human immunodeficiency virus (HIV)-associated pathology, Helicobacter pylori plays an important, but under-investigated part. Many HIV-infected patients have dyspeptic complaints and, though there is a recognized association between Helicobacter pylori and peptic ulcer among general population (1), the etiology of gastro-intestinal disorders varies greatly among HIV-positive subjects, ranging from opportunistic infections $(2,3)$ to medication adverse effects (4).

Several studies disputed over the prevalence of Helicobacter pylori infection among HIV-positive persons, reported to be either similar to $(5,6)$ or lower than the prevalence of the same infection in the general population $(2,7)$. Those depicting lower Helicobacter pylori infection rates among HIV-positive subjects incriminate the frequent use of antibiotics for opportunistic infections in severely immunocompromised patients, responsible for the accidental eradication of Helicobacter pylori (2). Besides, hypochlorhydria described in HIV-positive pa- tients by several authors $(8,9)$ may favor the development of various digestive opportunistic pathogens, competing with Helicobacter pylori for gastro-intestinal sites of infection (2).

Meanwhile, other researchers $(2,5)$ investigated the role played by the level of CD4+ T-cells in the acquisition of Helicobacter pylo$r i$ infection. Lower prevalence of Helicobacter pylori infection was noticed at CD4+ T-lymphocyte levels below 200cells/ $\mu \mathrm{L}$ (5). Other studies depicted a reduction in the frequency of Helicobacter pylori infection among severely immunosuppressed patients, with acquired immunodeficiency syndrome (AIDS) $(2,3,5,10-13)$.

Research examining the relationship between HIV-RNA plasma viral load (VL) and the presence of Helicobacter pylori has been rather poor, with reports of no statistically significant differences between HIV-RNA plasma VL among Helicobacter pylori positive and negative subjects (2).

Although research was performed in various countries around the globe, Helicobacter pylori HIV co-infection has not been sufficiently investigated in our geographic area, which provides space for the present study. 
The main purpose of this study was to assess the frequency of Helicobacter pylori infection among HIV-positive patients with dyspeptic complaints, compared to the HIV-negative population with similar symptoms. Secondary objectives were to investigate the importance of various factors associated with the presence of this microorganism in HIV-positive patients: the level of CD4+ T-lymphocytes, HIV-RNA plasma viral load, recent antibiotic treatment and the influence of antiretroviral therapy.

\section{Methods}

We performed a retrospective, analytical, case-control study, over a period of 26 months (November 2011 - December 2013), upon two groups of patients with dyspeptic symptoms (nausea, vomiting, upper abdominal pain, pyrosis) tested for Helicobacter pylori stool antigen at the Infectious Diseases Laboratory, Clinical County Hospital Mureş. Inclusion criteria were: the presence of dyspeptic symptoms - epigastric pain, nausea, vomiting, pyrosis - and adult age - over 18 years, while exclusion criteria were the lack of symptoms and pediatric age, under 18 years.

Group A consisted of 44 HIV-infected patients, while $58 \mathrm{HIV}$-negative subjects formed group B. The two groups were similar from the point of view of demographic features; age, gender and environment distribution. The presence of Helicobacter pylori antigen in stool was detected by qualitative immunochromatographic method (Laboquick Helicobacter pylori antigen test). The Committee for Research Ethics of the University of Medicine and Pharmacy Tîrgu-Mureş approved the present study.

After comparing the two groups from the point of view of Helicobacter pylori infection frequency, HIV-positive patients in group A were divided into two subgroups, according to the result of the test detecting Helicobacter pylori stool antigen. Subgroup A1 contained 5 Helicobacter pylori-positive subjects and subgroup A2 - 39 Helicobacter pylori-negative individuals. Apart from demographic data, we also collected comparative information regarding subgroups A1 and A2 patients' level of CD4+ T-lymphocytes, HIV-RNA plasma viral load, the stage of HIV infection according to the United States Centers for Disease Control and Prevention (CDC) classification, recent antibiotic and antiretroviral therapy, infectious and non-infectious co-morbidities.

Identification and determination of the absolute count of mature human helper / inducer (CD3+CD4+) $\mathrm{T}$ lymphocytes was performed by flow cytometry with three-color direct immunofluorescence reagent (CD4+/CD8/CD3) Becton-Dickinson. HIV-RNA viral load measurement was realized by real-time PCR, with Roche COBAS AmpliPrep COBAS TaqMan HIV-1 test.

Information regarding the patients' antibiotic and antiretroviral therapy, as well as their co-morbidities was obtained from the subjects' medical documents and prescription records. We only considered antibiotic substances active upon Helicobacter pylori and drug regimens dating up to six months previous to the date of $\mathrm{He}$ licobacter pylori stool antigen test.

Statistical analysis was performed with the aid of GraphPad Prism 5 program, by performing Mann-Whitney nonparametric test for comparing central tendencies and contingency table analysis - $\mathrm{Chi}^{2} /$ Fisher exact test, odds ratio (OR) calculation. We set the level of statistical significance at $\alpha=0.05$ for $95 \%$ confidence interval $(95 \% \mathrm{CI})$.

\section{Results}

Five $(11.36 \%)$ HIV-infected patients in group A and eight (13.79\%) HIV-negative subjects from group B tested positive for Helico- 
bacter pylori stool antigen. Fisher exact test did not reveal any statistically significant association between Helicobacter pylori infection and HIV status $(\mathrm{p}=0.77, \mathrm{OR}=0.80)$.

Groups A and B were similar from the point of view of age characteristics: median age 24 years in group A, 25 years in group B $(\mathrm{p}=0.53)$. Gender distribution was $29.55 \%$ male: $70.45 \%$ female in group A and 36.21\% male: $63.79 \%$ female in group $B(p=0.47)$. Urban: rural environment distribution scored $45.55 \%$ : $54.55 \%$ in group A, 56.90: $43.10 \%$ in group $\mathrm{B}(\mathrm{p}=0.25)$. (Table I, Figure 1)

According to the result of Helicobacter pylori stool antigen test, HIV-infected patients in group A formed two subgroups: A1, consisting of 5 Helicobacter pylori-positive subjects and
A2 - 39 Helicobacter pylori-negative individuals. The general characteristics of both subgroups are depicted in Table II.

We did not find statistically significant differences between the two subgroups regarding demographic features. Median age was 23 years in subgroup A1 and 24 years in subgroup A2 $(p=0.59)$. Gender distribution was $60 \%$ male: $40 \%$ female in subgroup A1 and 53.85\% male: $46.15 \%$ female in subgroup A2. Environment distribution was $60 \%$ urban: $40 \%$ rural in subgroup A1 and $43.69 \%$ urban: $56.41 \%$ rural in subgroup A2 ( $\mathrm{p}=0.64)$.

Two (40\%) subgroup A1 and 19 (48.72\%) subgroup A2 subjects had attended only primary school. All patients in subgroup A1 and 30

Table I. Demographic characteristics of groups A (HIV-positive patients) and B (HIV-negative patients).

\begin{tabular}{lccc}
\hline Characteristic & $\begin{array}{c}\text { HIV-positive patients } \\
\text { (group A): } \mathbf{~ ( \% ) ~}\end{array}$ & $\begin{array}{c}\text { HIV-negative patients } \\
\text { (group B): } \mathbf{~ ( \% )}\end{array}$ & P-value \\
\hline Gender & $13(29.55 \%)$ & $21(36.21 \%)$ & $\mathrm{P}=0.47$ \\
$\quad$ - Male & $31(70.45 \%)$ & $37(63.79 \%)$ & \\
$\quad$ - Female & $20(45.45 \%)$ & $33(56.90 \%)$ & $\mathrm{P}=0.25$ \\
\hline Environment & $24(54.55 \%)$ & $25(43.10 \%)$ & \\
$\quad$ - Urban & & & \\
- Rural & 24 & 25 & $\mathrm{P}=0.53$ \\
\hline Age (years) & $19-59$ & $18-61$ & \\
$\quad$ - Median & $24-29$ & $24-29$ & \\
- Minimum -Maximum & $-95 \%$ CI &
\end{tabular}

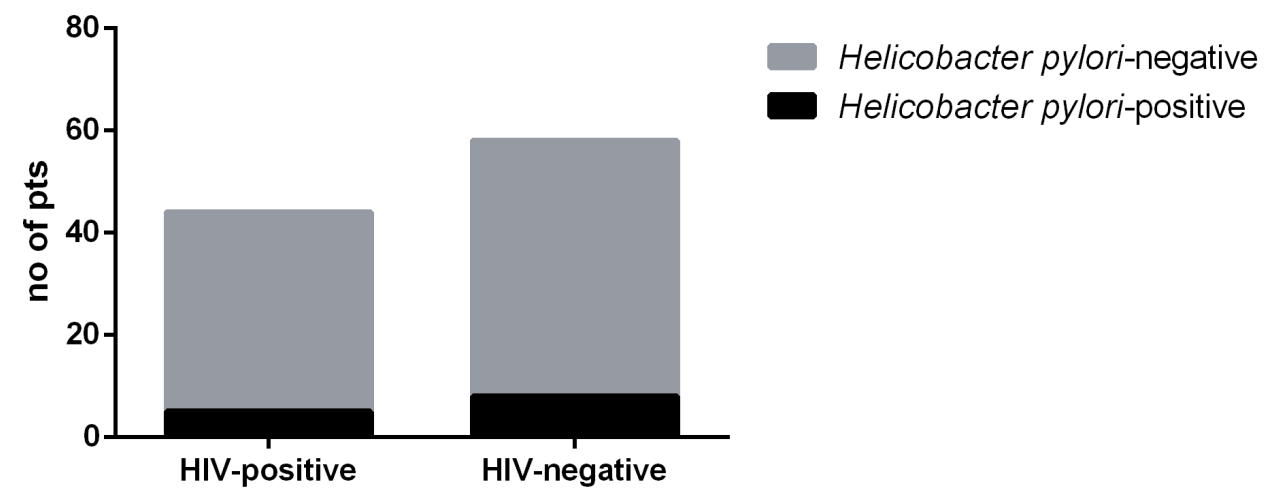

Figure 1. Frequency of Helicobacter pylori infection in HIV-positive versus HIV-negative patients 
Table II. General characteristics of Helicobacter pylori-positive (subgroup A1) and Helicobacter pylorinegative (subgroup A2) HIV-infected patients in our study.

\begin{tabular}{|c|c|c|c|}
\hline Characteristic & $\begin{array}{c}\text { Helicobacter pylori-positive } \\
\text { patients (subgroup A1) }: \mathrm{n}(\%)\end{array}$ & $\begin{array}{c}\text { Helicobacter pylori-negative } \\
\text { (subgroup A2) patients: n (\%) }\end{array}$ & P-value \\
\hline \multicolumn{4}{|c|}{ 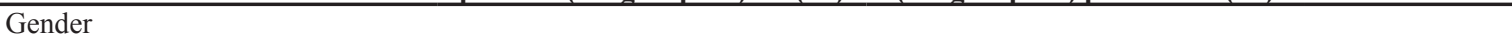 } \\
\hline - Male & $3(60 \%)$ & $21(53.8 \%)$ & \multirow[t]{2}{*}{$\mathrm{P}=1.00$} \\
\hline - Female & $2(40 \%)$ & $18(46.1 \%)$ & \\
\hline \multicolumn{4}{|l|}{ Environment } \\
\hline - Urban & $3(60 \%)$ & $17(43.5 \%)$ & \multirow[t]{2}{*}{$\mathrm{P}=0.64$} \\
\hline - Rural & $2(40 \%)$ & $22(56.4 \%)$ & \\
\hline \multicolumn{4}{|l|}{ Age (years) } \\
\hline - Median & 23 & 24 & \multirow{3}{*}{$\mathrm{P}=0.59$} \\
\hline - Minimum - Maximum & $21-28$ & $19-59$ & \\
\hline$-95 \% \mathrm{CI}$ & $21-28$ & $24-29$ & \\
\hline Education level (basic) & $2(40 \%)$ & $19(48.7 \%)$ & $\mathrm{P}=1.00$ \\
\hline Unemployment & $5(100 \%)$ & $30(76.9 \%)$ & $\mathrm{P}=0.56$ \\
\hline \multirow{2}{*}{\multicolumn{4}{|c|}{$\begin{array}{l}\text { CD4+ T-lymphocytes level (cells/ } \\
\mu \mathrm{L}) \text { : }\end{array}$}} \\
\hline & & & \\
\hline - Median & 661 & 273 & \multirow[t]{3}{*}{$\mathrm{P}=0.32$} \\
\hline - Minimum - Maximum & $5-1210$ & $6-1548$ & \\
\hline$-95 \% \mathrm{CI}$ & $30-1131$ & $250-474$ & \\
\hline $\begin{array}{l}\text { CD4+ T-lymphocytes count below } \\
200 \text { cells } / \mu \mathrm{L}\end{array}$ & $1(20 \%)$ & $15(38.46 \%)$ & $\mathrm{P}=0.63$ \\
\hline \multicolumn{4}{|l|}{$\begin{array}{l}\text { HIV-RNA plasma viral load level } \\
(\log ) \text { : }\end{array}$} \\
\hline - Median & Undetectable & 2.65 & \multirow{3}{*}{$\mathrm{P}=0.52$} \\
\hline - Minimum - Maximum & Undetectable -4.79 & Undetectable -6.42 & \\
\hline$-95 \%$ CI & $1.2-4.6$ & $1.5-3.4$ & \\
\hline \multicolumn{4}{|l|}{ CDC stage of HIV infection } \\
\hline B1 & $1(20 \%)$ & $2(5.1 \%)$ & \multirow{6}{*}{$\begin{array}{c}\mathrm{P}=1.00 \\
\text { (for } \mathrm{C} 3 \text { stage) }\end{array}$} \\
\hline B2 & - & $7(17.9 \%)$ & \\
\hline B3 & - & $1(2.5 \%)$ & \\
\hline $\mathrm{C} 2$ & $1(20 \%)$ & $4(10.2 \%)$ & \\
\hline $\mathrm{C} 3$ & $3(60 \%)$ & $25(64.1 \%)$ & \\
\hline & & & \\
\hline AIDS & $4(80 \%)$ & $30(76.92)$ & $\mathrm{P}=1.00$ \\
\hline \multirow{2}{*}{\multicolumn{4}{|c|}{$\begin{array}{l}\text { Number of hospitalizations } \\
\text { (previous } 12 \text { months) }\end{array}$}} \\
\hline & & & \\
\hline $\begin{array}{l}\text { - Median } \\
\text { - Minimum - Maximum }\end{array}$ & $1-5$ & $1-9$ & \multirow{2}{*}{$\mathrm{P}=0.89$} \\
\hline$-95 \%$ CI & $1-5$ & $2-4$ & \\
\hline \multicolumn{4}{|l|}{$\begin{array}{l}\text { Number of hospitalizations } \\
\text { (previous } 5 \text { years) }\end{array}$} \\
\hline - Median & 5 & 7 & \multirow{3}{*}{$\mathrm{P}=0.89$} \\
\hline - Minimum - Maximum & 4-27 & $1-37$ & \\
\hline$-95 \% \mathrm{CI}$ & $2-22$ & $8-16$ & \\
\hline $\begin{array}{l}\text { Recent antibiotic treatment } \\
\text { (previous } 6 \text { months) }\end{array}$ & $4(80 \%)$ & $33(84.6 \%)$ & $\mathrm{P}=1.00$ \\
\hline Bacterial infections & $4(80 \%)$ & $33(84.6 \%)$ & $\mathrm{P}=1.00$ \\
\hline Fungal infections & $0(0 \%)$ & $3(7.6 \%)$ & $\mathrm{P}=1.00$ \\
\hline Parasitic infections & $0(0 \%)$ & $4(10.2 \%)$ & $\mathrm{P}=1.00$ \\
\hline Mycobacterial infections & $2(40 \%)$ & $9(23.0 \%)$ & $\mathrm{P}=0.58$ \\
\hline HAART & $3(60 \%)$ & $26(66.6 \%)$ & $\mathrm{P}=1.00$ \\
\hline Smoking & $3(60 \%)$ & $23(58.9 \%)$ & $\mathrm{P}=1.00$ \\
\hline Alcohol intake & $0(0 \%)$ & $13(33.3 \%)$ & $\mathrm{P}=0.30$ \\
\hline $\begin{array}{l}\text { Anti-inflammatory drugs (steroidal } \\
\text { / NSAIDs) }\end{array}$ & $2(40 \%)$ & $22(56.4 \%)$ & $\mathrm{P}=0.64$ \\
\hline
\end{tabular}


(76.9\%) of those forming subgroup A2 were unemployed $(\mathrm{p}=0.56)$.

CD4+ T-cells count had a median level of 661 cells $/ \mu \mathrm{L}$ among Helicobacter pylori-positive patients and 273 cells $/ \mu \mathrm{L}$ in Helicobacter pylori-negative $\mathrm{HIV}$-infected patients $(\mathrm{p}=0.32)$. $20 \%$ subgroup A1 and $38.4 \%$ subgroup A2 patients had CD4+ T-cells count below $200 / \mu \mathrm{L}$ $(\mathrm{p}=0.63, \mathrm{OR}=0.40)$. We registered a negative $(\mathrm{OR}=0.40)$, but not statistically significant association $(\mathrm{p}=0.63)$ between CD4+ T-cells count below 200 cells $/ \mu \mathrm{L}$ and the presence of Helicobacter pylori. (Figure 2)

Median HIV-ARN plasma viral load was undetectable in subgroup A1 and registered a level of $2.65 \log$ in subgroup A2 ( $=0.52)$. (Figure 3 )

According to the CDC clinical and immunologic classification of HIV infection, 1 (20\%) subgroup A1 patients were in stage B1, $1(20 \%)$ stage C2 and $3(60 \%)$ stage C3, while 2 (5.1\%) subgroup A2 subjects were in stage B1, 7 (17.9\%) stage B2, 1 (2.5\%) stage B3, 4 (10.2\%) stage C2 and 25 (64.1\%) stage C3. We did not find a statistically significant association between the presence of Helicobacter pylori and stage C3 HIV-infection.

Four (80\%) subgroup A1 and 30 (76.9\%) subgroup A2 patients were in AIDS stage, with CD4+ T-lymphocytes level below 200 cells/ $\mu \mathrm{L}$ and / or an AIDS-defining illness. However, our study did not find a statistically significant association between AIDS and the existence of Helicobacter pylori.

Analyzing the number of hospitalizations within the previous 12 months, we registered a median of 3 in subgroup A1 and 2 in subgroup A2 $(p=0.89)$, while the median number of hospitalizations during the previous 5 years was 5 in subgroup A1 and 7 in subgroup A2 $(\mathrm{p}=0.89)$.

Four (80\%) subgroup A1 and 33 (84.6\%) subgroup A2 patients had undergone antibiotic therapy for various infectious co-morbidities within the previous 6 months, including antimicrobial substances effective against Helicobacter pylori. We did not register any statistically significant association between recent antibiotic therapy prescribed for extra-digestive indications and the presence of Helicobacter pylori

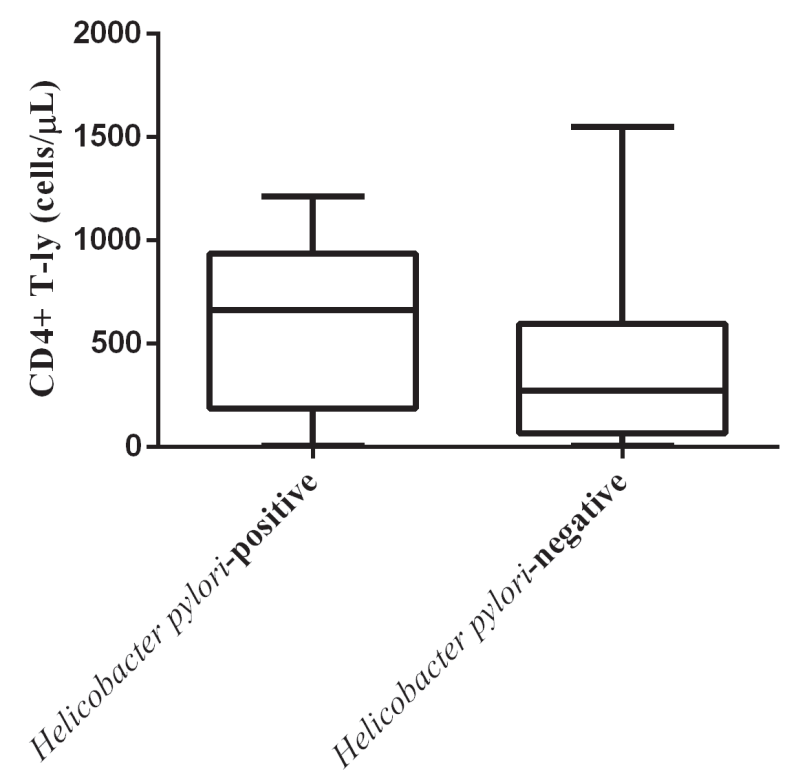

Figure 2. Helicobacter pylori infection and CD4+ T-lymphocytes level in HIV-infected patients 


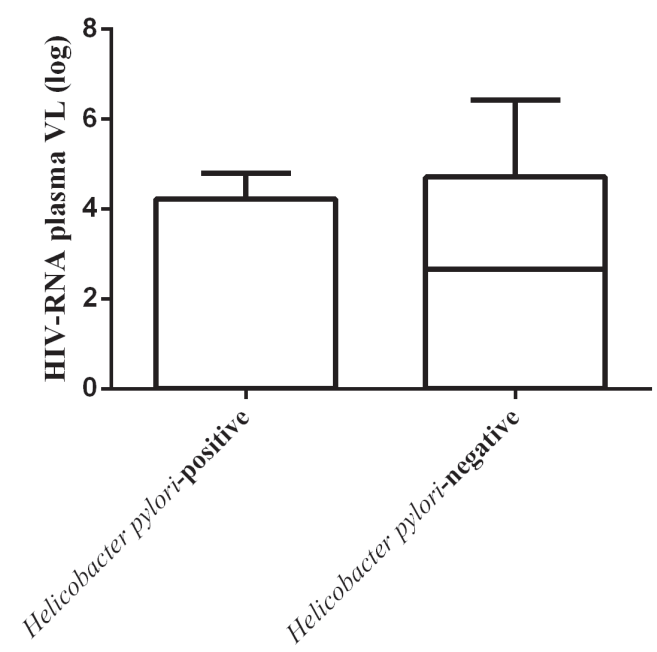

Figure 3. Helicobacter pylori infection and HIV-RNA plasma viral load in HIV-positive patients

infection. 3 (60\%) subgroup A1 and 26 (66.6\%) subgroup A2 subjects were under antiretroviral therapy (ARVT) - we did not register any statistically significant association between ARVT and the presence of Helicobacter pylori.

Both subgroup A1 and A2 patients suffered from various infectious co-morbidities. Bacterial infections were diagnosed in 4 (80\%) subgroup A1 subjects and $33(84.6 \%)$ subgroup A2 patients. We did not register fungal or parasitic infections in subgroup A1 patients, while 3 (7.6\%) subgroup A2 individuals were suffering from fungal illnesses and 4 (10.2\%) of them from parasitic diseases. Mycobacterial infections were detected in 2 (40\%) subgroup A1 and $9(23.0 \%)$ subgroup A2 patients $(\mathrm{p}=0.58)$.

HIV-infected patients in both subgroups also experienced independent risk factors for digestive illnesses, irrespective of Helicobacter pylori infection. Three (60\%) Helicobacter pylori-positive patients and $23(58.9 \%)$ Helicobacter pylori-negative ones were smokers. All 5 Helicobacter pylori-positive patients in subgroup A1 denied alcohol consumption, while 13 (33.3\%) admitted frequently drinking alcohol $(p=0.30)$. All subjects in both subgroups denied narcotics abuse. Two (40\%) subgroup A1 and 22 (56.4\%) subgroup A2 patients were receiving steroids / non-steroidal anti-inflammatory medication (NSAIDs), prescribed for associated illnesses $(p=0.64)$.

\section{Discussion}

Although the role of Helicobacter pylori in the pathogenesis of gastro-intestinal disorders - gastritis, peptic ulcer, gastric adenocarcinoma and mucosa-associated (MALT)-lymphoma - in the general population is well-known (1), the impact of this infection upon digestive pathology in HIV-positive hosts has not been extensively examined, so far. Considering the inhomogeneous literature data and the relatively sparse information regarding our geographic area, our study aimed at establishing the frequency of $\mathrm{He}$ licobacter pylori infection in HIV-positive compared to HIV-negative individuals with dyspeptic symptoms, as well as investigating various factors possibly correlated to its presence.

Our primary group of study consisted of 44 HIV-infected patients with dyspeptic symptoms, to which we paired a second group formed by 58 HIV-negative subjects with similar complaints. 
Although Helicobacter pylori infection may be asymptomatic, we included in our study only patients with digestive complaints, as we believed they would provide the highest chances for Helicobacter pylori detection. Since most HIV-positive patients in our study were young adults, concurring to the peculiar epidemiologic pattern of HIV infection in our country, it was important not to have statistically significant differences between the two groups (HIV-positive and HIV-negative subjects) regarding age characteristics $(\mathrm{p}=0.53)$, as the prevalence of Helicobacter pylori infection is known to vary with age: acquired in infancy in developing regions and during adulthood in industrialized countries (14).

The diagnostic method of choice in our study - Helicobacter pylori stool antigen detection via qualitative immunochromatographic assay - presented the advantage of non-invasiveness, since HIV-positive patients, frequently subjected to invasive diagnostic or therapeutic procedures for various opportunistic infections and malignant lesions, may prove reluctant to undergoing yet another invasive technique, which implies the discomfort of upper gastro-intestinal endoscopy.

In our study, Helicobacter pylori infection registered a frequency of $11.3 \%$ among HIV-positive patients, slightly lower than among HIV-negative subjects - $13.7 \%$, but not enough to provide a statistically significant association between the HIV infection and the presence of Helicobacter pylori $(\mathrm{p}=0.77, \mathrm{OR}=0.80)$. This was similar to the conclusion of some authors (5, 6 ), but different from others (2). The geographic area where the study was conducted may have significance. It is well known that Helicobacter pylori infection rates are higher in developing countries than in industrialized regions, related to socio-economic factors, level of hygiene, overcrowding, living conditions, education (14, 15). The diagnostic method of use may also be relevant, since several authors based their studies upon invasive diagnostic methods $(2,3)$, while other research was conducted using molecular diagnostic methods (6). In order to extend our study and better relate to literature data, the patients' accept to undergo upper gastro-intestinal endoscopy would be welcome.

The absence of a statistically significant difference regarding the frequency of Helicobacter pylori infection in HIV-positive and HIV-negative patients opens the gate for exploring other causes for dyspepsia in HIV-infected persons, ranging from fungal and viral digestive infections (3) to medication adverse effects (4), as some authors state than more than half of all HIV-positive individuals complain of gastro-intestinal symptoms (16).

Although it has been hypothesized that poor education, including incorrect sanitary practices, might indirectly influence the presence of Helicobacter pylori (14), we did not register statistically significant differences regarding the level of education $(\mathrm{p}=1.00)$ or lack of employment measure of the socio-economic status $(p=0.56)$ between subgroups A1 and A2. This could be explained by the high rates of unemployment and incomplete education among both subgroups of HIV-infected patients from our geographic area.

Among HIV-positive patients in our study, those infected with Helicobacter pylori registered slightly higher levels of CD4+ T-lymphocytes (median 661 cells $/ \mu \mathrm{L}$ ) than those who tested negative for Helicobacter pylori infection (median 273 cells $/ \mu \mathrm{L}$ ), although this did not result in a statistically significant difference $(p=0.32)$. This may be explained by the fact that poor immune status, reflected mainly by low CD4+ T-lymphocytes levels, favors the onset of opportunistic infections, some with gastro-intestinal location (17), thus competing against Helicobacter pylori for the same site of infection, as well as it increases the need of antibiotics, possibly leading to the accidental eradication of Helicobacter pylori (2). However, in order to achieve 
a statistically significant conclusion, we need to extend our research, increasing the number of studied patients.

Some studies depicted lower prevalence of Helicobacter pylori infection in patients with CD4+ T-cells $<200$ cells $/ \mu \mathrm{L}(5)$ and in AIDSstage subjects $(5,10-13)$. We did not find statistically significant associations between AIDS or C3 stage of HIV infection and the presence of Helicobacter pylori. However, there was a negative $(\mathrm{OR}=0.40)$, though not statistically significant association between CD4+ T-lymphocytes level $<200$ cells $/ \mu \mathrm{L}$ and Helicobacter pylori infection, which concurs to the tendency described in literature $(2,5)$.

As for the level of HIV-RNA plasma VL, we registered lower values among Helicobacter pylori-positive patients (median - undetectable) than among Helicobacter pylori-negative ones (median $2.65 \mathrm{log}$ ), although we did not find statistically significant difference between the two groups. This resembles other literature data (2), which did not report statistically significant differences between Helicobacter pylori-positive and -negative patients regarding the level of HIV-RNA plasma viral load.

The number of previous hospitalizations did not differ in a statistically significant way between subgroups A1 and A2, whether they were counted during the previous 12 months or 5 years, although most hospitalizations were caused by infectious co-morbidities and one would be tempted to think that antibiotic treatment undergone by these patients during hospitalization could have led to the eradication of Helicobacter pylori. Neither did we find statistically significant difference between Helicobacter pylori-positive and -negative patients regarding the use of antibiotics during the previous 6 months, similar to some literature data (2). Patients in both subgroups had high rates of antibiotic treatment, connected to high frequency of bacterial infections, possibly correlated to the high number of AIDS-stage subjects registered in both Helicobacter pylori-positive and -negative categories from our study. As supplementary research opportunity, we suggest analyzing the route of administration of antibiotic treatment, as oral versus parenteral route may offer different access to the digestive site of Helicobacter pylori infection.

Another interesting issue would be the association between highly active antiretroviral therapy (HAART) and the presence of Helicobacter pylori, as the main purpose of antiretroviral therapy is to inhibit viral replication, leading to an increase in the level of CD4+ T-lymphocytes and decrease of HIV-RNA plasma viral load, thus reducing the risk of opportunistic infections and the need for antibiotic therapy. However, our study did not reveal a statistically significant difference between antiretroviral treatment and the presence of Helicobacter pylori, similar to other literature data (2).

As we review the somehow poor statistical differences between subgroups A1 and A2, we must consider the presence of independent risk factors for digestive illnesses in both studied subgroups, at similar and usually high rates: smoking, alcohol abuse $(p=0.30)$, anti-inflammatory medication $(p=0.64)$, factors which are known to impact upon the state of the gastro-intestinal tract of the general population (18). Apart from this, there are studies suggesting an increase in number of non-HIV-associated digestive illnesses in HIV-infected patients during the "HAART era", concomitant to a decrease in the frequency of opportunistic infections in patients under antiretroviral therapy (19).

While research is needed upon larger groups of patients, adding invasive diagnostic methods, in order to clarify potentially diverging results between our study and other authors' conclusions, one must bear in mind geographic region differences among various groups of study. 


\section{Conclusion}

Our study did not reveal any statistically significant difference between the frequency of Helicobacter pylori infection among HIV-positive and HIV-negative subjects with digestive complaints. This suggests the need to investigate alternative etiologies for dyspepsia in HIV-positive patients, besides Helicobacter pylori infection.

HIV-positive subjects co-infected with $\mathrm{He}$ licobacter pylori tend to have higher levels of CD4+ T-lymphocytes than patients who are not infected with this Gram-negative rod.

HIV-positive patients with severely impaired immune status, reflected by CD4+ T-lymphocyte levels below 200 cells $/ \mu \mathrm{L}$, are less probable to be infected with Helicobacter pylori.

Helicobacter pylori-positive HIV-infected subjects tend to have lower levels of HIV-RNA plasma viral load than Helicobacter-pylori-negative ones.

Both Helicobacter pylori-positive and Helicobacter pylori-negative HIV-infected subjects experience various other risk factors for gastro-intestinal diseases.

\section{Acknowledgements}

This paper is partly supported by the Sectorial Operational Programme Human Resources Development (SOP HRD), financed from the European Social Fund and by the Romanian Government under the contract number POSDRU 80641.

\section{Statement on conflicts of interest}

None of the authors has any potential conflict of interest regarding this paper.

\section{Abbreviations}

HIV - human immunodeficiency virus
CD4+ - cluster of differentiation 4

$\mu \mathrm{L}-$ microliter

AIDS - acquired immunodeficiency syndrome

RNA - ribonucleic acid

VL - viral load

CDC - Center for Diseases Control and Prevention

PCR - polymerase chain reaction

OR - odds ratio

95\% CI - 95\% confidence interval

Log - logarithm to base 10

ARVT - antiretroviral therapy

NSAIDs - non-steroidal anti-inflammatory drugs

MALT - mucosa associated lymphoid tissue

HAART - highly active antiretroviral therapy

$\mathrm{n}$ - number

Pts - patients

Ly - lymphocytes

\section{References}

1. Atherton JC, Blaser MJ. Helicobacter pylori infections. In Kasper DL, Fauci AS. Harrison's Infectious Diseases. McGraw Hill Medical, NY. 2010;506-11.

2. Fialho ABC, Braga-Neto MB, Guerra EJC, Fialho AMN, Fernandes KC, Sun JLM et al. Low prevalence of $\mathrm{H}$. pylori infection in HIV-positive patients in the Northeast of Brazil. BMC Gastroenterology. 2011 Feb;11:13. DOI: 10.1186/1471-230X-11-13

3. Chiu HM, Wu MS, Hung CC, Shun CT, Lin JT. Low prevalence of Helicobacter pylori but high prevalence of cytomegalovirus-associated peptic ulcer disease in AIDS patients: Comparative study of symptomatic subjects evaluated by endoscopy and CD4+ counts. J Gastroenterol. 2004 Mar;19:423-8.

4. Schiefferstein-Knauer C, Buhk T. Management of side effects. In Hoffmann C, Rockstroh JK. HIV 2012/2013, Medizin Fokus Verlag, Hamburg. 2012;264-7.

5. Olmos M, Araya V, Pskorz E, Quesada EC, Concetti $\mathrm{H}$, Perez $\mathrm{H}$ et al. Coinfection: Helicobacter pylori / human immunodeficiency virus. Dig Dis Sci. 2004 NovDec;49(11-12):1836-9. DOI: 10.1007/s10620-0049580-5

6. Kafil HS, Jahromi FF, Hajikhani B, Pirayeh SN, Aghazadeh M. Screening for the presence of Helicobacter pylori in stool of HIV-positive patients. JAHR. 2011 Apr;3(4):85-7.

7. Șincu NI, Bățagă S, Chiriac C, Țilea B, Zaharia-Kez- 
di I, Incze A, et al. Helicobacter pylori infection in HIV-positive versus HIV-negative patients. Acta Medica Marisiensis. 2012;58(6):454-7.

8. Sulkowski MS. Gastrointestinal and hepatobiliary manifestations of human immunodeficiency virus infection. In Mandell GL, Bennett JE, Dolin R, editors: Mandell, Douglas, and Bennett's Principles and practice of infectios diseases, 7th edition, Churchill Livingstone Elsevier, Philadelphia. 2010, 1737-44. DOI: 10.1016/ B978-0-443-06839-3.00123-5

9. Welage LS, Carver PL, Revankar S, Pierson C, Kauffman CA. Alterations in gastric acidity in patients infected with human immunodeficiency virus. Clin Infect Dis. 1995 Dec;21(6):1431-8. DOI: 10.1093/clinids/21.6.1431

10. Romanelli F, Smith KM, Murphy BS. Does HIV infection alter the incidence or pathology of Helicobacter pylori infection? AIDS Patient Care STDS. 2007 Dec;21(12):908-19. DOI: 10.1089/apc.2006.0215

11. Mach T, Skwara P, Biesiada G, Ciesla A, Macura A. Morphological changes of the upper gastrointestinal tract mucosa and Helicobacter pylori infection in HIV-positive patients with severe immunodeficiency and symptoms of dyspepsia. Med Sci Monit. 2007 Jan;13(1):CR14-9.

12. Lichterfeld M, Lorenz C, Nischalke HD, Scheurlen C, Sauerbruch T, Rockstroh JK. Decreased prevalence of Helicobacter pylori infection in HIV patients with AIDS defining diseases. Z Gastroenterol. 2002;40(1):11-4. DOI: $10.1055 / \mathrm{s}-2002-19637$
13. AliMohamed F, Lule GN, Nyong'o A, Bwayo J, Rana FS. Prevalence of Helicobacter pylori and endoscopic findings in HIV seropositive patients with upper gastrointestinal tract symptoms at Kenyatta National Hospital, Nairobi. East Afr Med J. 2002 May;79(5):226-31.

14. Khalifa MM, Sharaf RR, Aziz RK. Helicobacter pylori: a poor man's gut pathogen? Gut Pathogens. Gut Pathog. 2010 Mar;2(1):2. DOI: 10.1186/1757-4749-2-2

15. Calvet X, Ramirez Lazaro M-J, Lehours P, Megraud F. Diagnosis and epidemiology of Helicobacter pylori infection. Helicobacter. 2013 Sep;18(s1):5-11. DOI: 10.1111/hel.12071

16. Bhaijee F, Subramony C, Tang SJ, Pepper DJ. Human immunodeficiency virus-associated gastrointestinal disease: common endoscopic biopsy diagnoses. Patholog Res Int. 2011 Apr;2011:247923. DOI: $10.4061 / 2011 / 247923$

17. Wilcox CM, Saag MS. Gastrointestinal complications of HIV infection: changing priorities in the HAART era. Gut. 2008 Jan;57:861-70. DOI: 10.1136/ gut.2006.103432

18. Malfertheiner P, Chan F, McCall K. Peptic ulcer disease. Lancet. 2009 Aug;374:1449-61. DOI: 10.1016/ S0140-6736(09)60938-7

19. Nkuize M, De Wit S, Muls V, Arvanitakis M, Buset M. Upper gastrointestinal endoscopic findings in the era of highly active antiretroviral therapy. HIV Medicine. 2010 Feb;11(6):412-7. DOI: 10.1111/j.14681293.2009.00807.x 